\title{
The Innovative Practice of Applied Talents Training Mode in Civil Engineering
}

\author{
Zaibo Li \\ School of Civil Engineering \\ Shaoguan University \\ Shaoguan, People’s Republic of China
}

\author{
Yongping Zhang \\ School of Foreign Languages \\ Shaoguan University \\ Shaoguan, People’s Republic of China
}

\begin{abstract}
Lack of innovative applied talents is the bottleneck problem of the current scientific and technological innovation and enterprise development. In order to solve this problem, the innovation talents' training mode scheme was designed and carried out. Applied undergraduate education of civil engineering makes innovative practice for the personnel training mode and establishes the training objective of high-quality applied talents for construction and management in civil construction enterprises. Practice shows that students' comprehensive quality and engineering ability have enhanced considerably by establishing the training mode of innovative talents, and it is very effective in practice.
\end{abstract}

Keywords-Civil engineering; Personnel training mode; Applied undergraduate education

\section{INTRODUCTION}

Civil engineering is a traditionally applied specialty. With the continuous extension of national infrastructure and civil construction scale, the social demand for advanced technical talents of civil construction is very urgent and the high expectation has been rendered [1]. The enterprises of civil construction expected that the graduates of civil engineering specialty should not only be equipped with higher occupational qualities and professional ability but also be qualified for various technical management posts of project department in civil engineering construction enterprises in a short period of time, and thus enterprises can adapt quickly to the developmental need of national civil construction [2].

Shaoguan University's applied undergraduate education of civil engineering actively adapts to the reality of social development and actively served need of civil engineering development, and makes innovative practice for the personnel training mode of applied undergraduate education in civil engineering; and establishes the training objective of highquality applied talents for construction and management in civil construction enterprises; and builds the curriculum system that lays emphasis on post pertinence, focuses on actual demand of the posts, and confirms the curriculum system that centers on theoretical knowledge needed by specialty or technical posts and technical skills; and constructs teaching contents that combine professional education with industrial practicing requirements and skill training with engineering ability, and the cultivating mode of innovative talents that designed for students' growth and development, and thus

This research was financially supported by the Foundation of Shaoguan University (SYJY20171811). gained better practice effect [3].

\section{The POST ANALYSIS OF GRADUATES FROM CIVIL ENGINEERING SPECIALTY}

From the survey statistics of the civil engineering graduates' employment orientation in local undergraduate colleges nationwide, it shows that students work on construction technique occupy about $70 \%$, administrative work of civil engineering about $7 \%$, designing about 15\%, building trade and comptroller about 3\% and other industries about 5\% [4]. From the statistic data, it is obvious that most graduates are engaged in construction technical work in the first production line. From the civil engineering graduates' work orientation in recent years, it also shows that the graduates employed in designing organizations are less and less while those in construction companies increase year by year. This phenomenon demonstrates that the civil engineering talents trained by local colleges and universities are mostly in the frontline of production and management. Furthermore, employers usually require the new staff to be equipped with stronger practical work experience and to work soon, while the newly graduated students are short of practical experience and are often rejected by employers [5].

Industrial technicians' shortages of cognition degree for the knowledge of civil construction industry, occupational qualities and professional ability restrain the technological development of civil engineering, so there is an urgent need for a large number of high-level applied professional technicians in this industry [6]. As a result, it is necessary to accelerate the exploration and practice of cultivation mode for innovative applied talents so that the social service value of civil engineering specialty in undergraduate education can be realized.

\section{The InNOvative Practice Of Cultivation Mode FOR APPLIED CIVIL ENGINEERING TALENTS}

\section{A. The project design on the cultivation mode of innovative talents}

According to the social demand, the professional and industrial features of civil engineering should be highlighted, and thus confirm the applied civil engineering talents' primary employment orientation that is building construction engineering, which is primarily about the posts of construction project department and the design and construction of its 
attaching professional direction, such as geotechnical and road engineering, and then the training objective was confirmed on these bases.

The professional knowledge, ability and quality were established on the thread of the cultivation applied ability in engineering technology and basic quality. According to the civil engineering graduates' employment orientation and training objective, the graduates' knowledge, ability and competence structure have been confirmed reasonably on the basis of consulting broadly the experts' opinions [7].

Based on the graduates' specialized knowledge, ability and quality structure, and social demand for talents, the teaching content and systems of theoretical curriculum and practical teaching have been established, and meanwhile, the teaching model and teaching system that are suitable for teaching objective have been established.

Based on the teaching objective and combined with the demands for society and students' employment, the establishment of applied undergraduate education is not only with specific job orientation and post-presidency but also with extensive job adaptability, and meanwhile not only with the principal direction of work upon graduation and a wide range of knowledge, but also with the new teaching model that can suit the multiple auxiliary aspects on the demands for society and employment.

Based on the demand for the cultivation of students' application ability on skills and comprehensive quality, the theoretical teaching system and teaching contents have been established optimally. On the aspect of vocational ability, pertinence, practicability and integrity have been highlighted; and on the consideration of the theoretical curriculum system, the main line of the ability for technology application and the cultivation of comprehensive quality have been established, and at the same time the modular-based curriculum system that meets the demands of society and employment has been established.

According to the demands for cultivating students' application ability on skills and comprehensive quality, the practical teaching system and teaching content have been structured. In establishment, the point that the practical teaching system and the theoretical teaching system are equally important has been emphasized, and they are not only relatively independent and on their own systems but also centers on the main line of cultivating technology application. The practical teaching system and the theoretical teaching system connect closely, permeate mutually and collectively complete the professional knowledge imparting and cultivating practical work ability. Following the respective training features of experiment skills, operating skills, monomial skills of post and integrated skills of post to organize practical teaching should be emphasized, and meanwhile combining skill training evaluation with social occupational qualifications test and technical grades identification should be emphasized. The cultivation of autonomous learning ability and innovative ability should be stressed.

\section{B. The practice of training mode for innovative talents}

In order to carry out talents training mode and realize the training objective, the training mode of innovative talents should break the original subject system and be conducted by dividing the whole teaching contents into 4 modules. The first module is cultivating the overall quality of personal ability, and it is about the basic ability, including humanistic society, legal knowledge and professional ethics. The second module is about professional and technical basis, which emphasizes the prominence of computer application ability, numeracy, mobility in a relevant domain, reference ability for materials in other languages, and the ability to chart and recognizing graphs, etc. The third is a technical capacity module, which highlights the abilities of engineering design and construction, etc. The fourth is a management skill module, which highlights the abilities of management, accounting, finance, bidding and tendering decisions, quality, and safety management, etc.

Establish and perfect practice base matched with new teaching system on and off-campus and matched teaching and assessment mechanism, and implement the training mode of the multi-certificate system, such as certificates of foreign languages, computer ranks and vocational skill qualification. In this way, the graduates' real operational ability and social practice ability can be enhanced.

Construct the practical teaching system in the mode of college-enterprise cooperation. For this goal, it's necessary to optimize the practical teaching content of civil engineering and establish the progressive practical teaching system in engineering, that is: teaching-internship - ability. Meanwhile, to build more practical teaching subjects and improve the students' practical ability in engineering, that is to say, the ability to analyze and solving the practical problems with various in engineering. The practical teaching links with high requirements and long time, such as cognition practice, production practice and graduation practice, should be arranged in the work units of civil engineering construction in the form of groups. In practice, intern students can involve in the work of construction, management, and design, etc. The interns are required to use various professional skills and knowledge and solve the problems in construction technique, production organization, and engineering supervision with the management of construction technology production organization.

Establishing a diversified professional double-quality teacher team. The experts with superior achievements and rich experience in construction and management, and the young and middle-aged academic leaders should be brought in as cadre teachers on-campus practical teaching. At the same time, based on the teaching needs the technicians from enterprises and institutions with strong responsibility in work, love for the educational cause and consummate techniques should be chosen and hired as the long-term external faculty team. The organic integration of the cadre teachers and eternal faculty team laid a solid foundation for establishing a high-caliber professional double-quality teacher team. Meanwhile, the professional teachers make use of vacation and work in the enterprises' first production line to practice on the planned arrangement, which can improve the teachers' professional 
skills and horizons. Based on the above situation, in order to keep the close interrelation between curriculum content and production practice, enterprise engineering technicians and experts will be hired to teach in college.

As far as students' comprehensive quality ability and social evaluation, the cultivation mode of applied civil engineering talents have carried out for 5 years, and has gained a better practice effect. Students' knowledge and ability have been developed harmoniously, which effectively promotes the cultivation of students' creative thinking, self-study ability, personality traits, the advancement of practice ability and personality development. In theory teaching, we not only lay emphasis on the instruction of basic conception and theory but also pay efforts to enhance students' ability in the comprehensive application of knowledge and theory, so students' practical ability has improved considerably. The practical teaching mode has promoted the students' advancement in the application ability of engineering technology. The implementation of this project involves various fields of civil engineerings, such as, design, construction, engineering projects management, which can stimulate students' learning interest and innovative ability. The graduates of civil engineering specialty have gained recognition in higher evaluation from society and enterprises.

\section{Improving social services level}

Make full use of the teaching condition-the civil engineering building in our school to simulate enterpriseoriented teaching sites, which is featured in the environment. In this area, the students are regulated strictly based on the enterprise-style, while they are cultivated with the professional quality and skills in college. Served as a social service site, the civil engineering building in our school can bring the businesses of engineering design and engineering cost consultation, which are undertaken by individual teachers or by colleges, into college to get unified management. It can standardize the social service management, improve the social service level, expand the social service specifications, improve the social service income and enhance the social service ability of teachers and students. In this way, the ultimate goal of improving the talents' cultivation level can be reached, and thus, during the academic years students can come into contact with the real engineering projects.

\section{CONCLUSION}

Through the establishment and practice of training mode for the talents of applied undergraduate education in civil engineering, training high-level technical application-type on civil engineering that suit new techniques and construction equipment and meet modern civil engineering should be realized deeply. The training program and mode must be established in the cultivation of engineering ability and the improvement of students' comprehensive quality, and meanwhile, highlight the application ability and innovative ability in engineering technology, so the following five aspects should be completed well in innovative practice:

1. Innovating theoretical teaching system. In building the innovative theoretical teaching system, based on the structural demand for specialized knowledge, ability, and quality in civil engineering, the curriculum system and content have been optimized and combined, and meanwhile the theoretical teaching system that is suitable for training objective has been established.

2. Innovating practical teaching system. In building the innovative practical teaching system, based on the structural demand for specialized knowledge, ability, and quality in civil engineering, the practical teaching system and content have been optimized and combined, and the practical teaching system that suits the training objective should be established. That includes the teaching systems of experiment and various internship and design, such as civil engineering materials, soil mechanics, etc.

3. Innovating the teaching mode. In establishing teaching mode, the .curriculum can be divided into the comprehensive quality course, basic theoretical course and technical competence, etc., which can make the curriculum system be beneficial to complete training objective.

4. Innovating the teaching mode. The classroom teaching mode of students' active participation and bilateral interaction between students and teachers and the practical teaching mode of technology promotion and application have been established. Using the progressive teaching mode: classroom-siteclassroom-practice, let students become the host of teaching and make teaching alive.

5. Strengthening the build of training base and improving students' engineering ability. The establishment of the internship and training bases in and outside school, which are suitable for politics, production, learning and research, is beneficial to cultivate students' vocational ability and improve comprehensive ability, so it can lay a solid foundation for the improvement of students' engineering ability.

\section{REFERENCES}

[1] CHEN Yi-hu. Practice Mode of Applied Talents Training Based on Post Matching for Civil Engineering Specialty, Education Teaching Forum, 2018,(46),33-34. (In Chinese)

[2] LI Guoqiang. A Discussion on the Present Characteristic of China's Higher Education Development, Journal of Higher Education, 2017, (07) 16-22. (In Chinese)

[3] WANG Xiangting. Deepening Reform of Talent Training Mode and Enhancing Innovative and Practical Ability of Undergraduates, Experimental Technology and Management, 2014, (09): 19-21. (In Chinese)

[4] CHEN Guixiang. On the Formation of Innovative and Entrepreneurial Talents Cultivation Mechanism with Linkages among University, Government and Enterprise, University Education Science, 2015, (01): 42-47. (In Chinese)

[5] GUO Wenli. Transformation and Construction Training Mode Reform of Application-oriented Engineering Talents in Local Universities with Industry Background, Research in Higher Education of Engineering, 2012, (04): 25-33. (In Chinese)

[6] WU Aihua, Liu Xiaoyu. Promoting the Cooperation between Universities and CAS Institutions for Talent Cultivating, Research in Higher Education of Engineering, 2015, (02): 6-9. (In Chinese)

[7] YUAN Jun. Discussion on the teaching mode of engineering geology course based on the training of applied talents' case on the road and bridge direction of civil engineering specialty, Journal of Architectural Education in Institutions of Higher Learning, 2017,26(05),50-53. (In Chinese) 